\title{
INTERNATIONAL REGION AS A BRAND ORIGIN: CONCEPTUALIZATION AND REVIEW
}

\author{
Eugenijus Chlivickas ${ }^{1}$, Rasa Smaliukienė ${ }^{2}$ \\ International Economics and Management Department, Vilnius Gediminas Technical University, \\ Saulètekio al. 11, 10223 Vilnius, Lithuania \\ E-mails: ${ }^{1}$ Eugenijus.Chlivickas@vv.vgtu.lt ; ${ }^{2}$ rasa.smaliukiene@vv.vgtu.lt \\ Received 10 May 2008; accepted 19 March 2009
}

\begin{abstract}
The purpose of the paper is to examine the international region-relation as a brand origin. The results of the theoretical analysis of this study provide a foundation for making suggestions about theoretical relationships between components of the brand origin. According to proposed theoretical model, communication with the consumers spreading from the strong business clusters in the international region creates emotional attitudes towards a brand origin; in addition, the quality of the products of the same clusters creates cognitive attitudes towards a brand origin. Our interest centred on a specific international area - the Baltic Sea region. This region embodies the principles of shared values and common purpose, hence portrays a promising situation for regional branding. Performed empirical research allowed the analysis of both emotional and cognitive components of the brand origin. Therefore, the direct effects of the attributes of local brands on the brand origin were tested on the basis of telecoms and food industries in the Baltic Sea region.
\end{abstract}

Keywords: brand origin, Baltic Sea region, international region, emotional and cognitive components.

\section{Introduction}

The relationship between brand origin and product image has long been the central theme of research on branding; however, business internationalization effects clear boundaries between countries and challenges the perception of a brand origin. Moreover, the variety of international cooperation, international clustering, and manufacturing in low pay countries trouble the positioning of products. The development of broader perception of a brand origin is supposed to be one of the strategies to overcome such a challenge. The present research discusses some solutions on how to compete effectively in the presence of international region-related intangible assets. Thereby, our study provides suggestions for business clusters. In particular, the purpose of this research is to examine the international region-relation and transform it into a brand.

Our interest centred on a specific international area the Baltic Sea Region. This region embodies the principles of shared values and common purpose better than any other region (Mrugank 1996 ) and outlines many advantages for regional branding. Furthermore, companies in the Baltic Sea Region have become increasingly active in cluster and competitiveness efforts in the national and global markets (Van Ittersum et al. 2003). Baltic Development Forum is exploring the possibility to brand this region as the "top of Europe" not only geographically, but also in terms of economic growth, educational levels, innovation, research and development (Ahmed and d'Astous 2008). Taken together these elements portray a promising situation for regional branding; however, a strategic marketing question whether this region is attractive enough to serve as a brand arises.

This article reviews the brand origin literature, presents the definition of brand origin in international region, and clarifies the relationship between product brand image and international region image. The empirical study was designed to test the theoretical model and hypotheses and to expand the relatively few existing empirical studies on international region as a brand origin. Data for this study was collected through an Internet survey of emigrants from the Baltic Sea Region as international customers. The research was based on the residents in the UK and Spain. These areas were 
selected as they are geographically dispersed and were expected to have variations in customers' perception. It was decided to study the model for food and telecommunication service products. These product categories were chosen because most consumers are familiar with these products and purchase them on a regular basis.

The theoretical value of our study lies in the synthesis of fragmented knowledge about branding international region. It provides some theoretical framework for international region-related branding and presents the results of empirical research based on the Baltic Sea region as a brand origin. From the practical standpoint the paper provides understanding of the influence of regional image on products positioning in international market.

\section{Literature review}

In this section, we firstly characterize the definition of brand origin as the most preferable concept for analysing a product place phenomenon. Next, we present the definition of brand origin in international region as one of the solutions for branding international business. Then, we outline the theoretical framework of brand origin by connecting two complementary views, where one describes the effect of brand origin on stereotyping the perception of products, while the second depicts a few brand origin associations as the outcome of wellknown brand names of particular product.

To begin with, brand origin is a place, region or country to which the brand is perceived to belong by its target consumers (Mrugank 1996 ). The influence of a brand origin on a product evaluation has mainly been studied from a country-of-origin perspective (Van Ittersum et al. 2003). A number of studies disclose the importance of the country image to the customer buying decisions by analysing the relationship between country evolution and manufacturing dimensions of a product. As the concept of a product made in a single country is no longer totally representative of today's market-place reality (Ahmed et al. 2002), we should be cautious in analysing the single product place phenomenon and the impact of country-of-origin. The unsolvable problem for the studies on country-oforigin remains the internationalization of business, when manufacturing dimensions such as the country of design and the country of assembly are different. Big differences between the factors that determine the perception of country-of-origin confuse the customers and decrease the influence of a brand. Brand origin as a concept and as a reference to the large territory can reasonably solve this problem; therefore, we use the term 'brand origin' in this study.

Since international regions are less homogeneous in terms of social, economic and political factors than countries, only a few studies are focusing on international region as a brand origin. Heterogeneous regions involve highly industrialized countries where the products are designed and newly industrialized countries where the products are manufactured. From this viewpoint, international regions are very attractive as a brand origin for international business. At the same time, representing the ultimate level of complexity, the development and management of regional brands crossing nations and cultures currently lack any empirically researched systematic theory (Kaufmann and Durst 2008). By analysing international regions as a brand origin we focus on regional similarities. In this way, the international region is perceived as one entry or an area with common components that are different from those of surrounding areas (Alexander et al. 2001). From the brand origin perspective, international brands can achieve a positive regional positioning by focusing on regional innovativeness (Cayla and Eckhardt 2007) and dynamics. This focus can be reached by stressing on associations with highly industrialized countries as prospective innovators and with new industrialized countries as the potential for growth and changes. Therefore presenting international region as a brand origin we are increasing its attractiveness by linking two positive attributes - innovativeness and dynamics. At the same time we do not confuse consumers with dual manufacturing dimensions if the country of design and the country of assembly are different.

The argumentation on brand origin as an up-to-date concept and the discussion on international region as a brand origin led us to some theoretical framework. Detailed review below on this topic brings specific instruments and linkages between the elements in this theoretical framework.

A great number of studies substantiate the idea of brand origin as a construct of emotional and cognitive components where researchers define the cognitive component as knowledge about physical attributes, while the affective component as feelings towards the attributes. The cognitive components explain why consumers may rationally think that a certain country is expert at some product categories, but overall negative feelings associated with the country may lead to negative behavioral consequences (Han et al. 2005). When consumers are highly motivated, they tend to use cognitive components by evaluating products according to their brand origin (Karunaratna and Quester 2007); but when motivation is low, individuals may use emotional cues to form attitudes (Gürhan-Canli and Maheswaran 2000).

Theoretical analysis reveals two complementary views on brand origin. The representatives of the first research direction argue that consumers use the information on brand origin to evaluate products and that 
the place of origin influences evaluations by signalling product quality (Moon and Jain 2002). The economic, social and cultural systems of countries as well as their relative stage of economic development are pieces of information which serve to position countries hierarchically in consumers' mind (Ahmed and d'Astous 2008). Most of the studies indicate that the image of brand origin depends on the perception of the level of economic development of the country (Roth and Romeo 1992). The higher economic development of a country, the more positive is the perception of the product quality (Ahmed and d'Astous 2007). From this perspective, the development of international region as brand origin solves the problem when the product from less industrialized country is perceived by consumers as less reliable.

The scholars of the second direction show the relationship between single brand origin and the associations with other brand names from the same place. The direction of this research is based on the idea that the familiarity with products made in a country is the strongest predictor of country perceptions, followed by nationality and the manufacturing process and product complexity dimensions of country evaluation (Ahmed and d'Astous 2008). Therefore, perceived origin associations are evident within brand names, created through long term communication with the consumers. According to that, the brand origin is a construct consisting of affective and cognitive components.

\section{Conceptual model and hypotheses}

Following the review on the literature concerning the concept of brand origin, let us now propose a conceptual model. Since the effect of a brand origin has been mainly studied from the country-of-origin perspective
(Van Ittersum et al. 2003), the country-of-origin literature is used as the main source for our model and hypothesis. Specifically, we continue the second direction of the brand origin studies and analyse the effect of communication on the associations with origin.

We deal with the simplest model that will suffice to isolate the forces in question. The main forces for the discussion are visualized in Fig. 1. According to our theoretical model it is predicted that communication with the consumers spreading from the strong business clusters ( $\mathrm{X}$ and $\mathrm{Y}$ in part I of the figure) in the region creates emotional attitudes towards a brand origin. At the same time, the quality of the products of the same clusters creates cognitive attitudes towards a brand origin. Both of these attitudes make an impact on the associations that consumers experience with the single origin. This point is essential in our model as it solves one of the main problems which appear in analysing the general images of the region and explain the product-specific influence on the origin. Based on the results from the previous studies and taking generally accepted approach we hypothesize:

H 1: The products from the industries of high employment intensity and dominance in the regional economy create the main emotional and cognitive associations with brand origin.

The image of the region has been created by dominant industries and it is descending to other industries of the same origin. Consequently, the attitude towards the new product depends on the image consumer holds onto that origin (Van Ittersum et al. 2003). It has been expected that the association with brand origin will synergize with the associations of new products of the

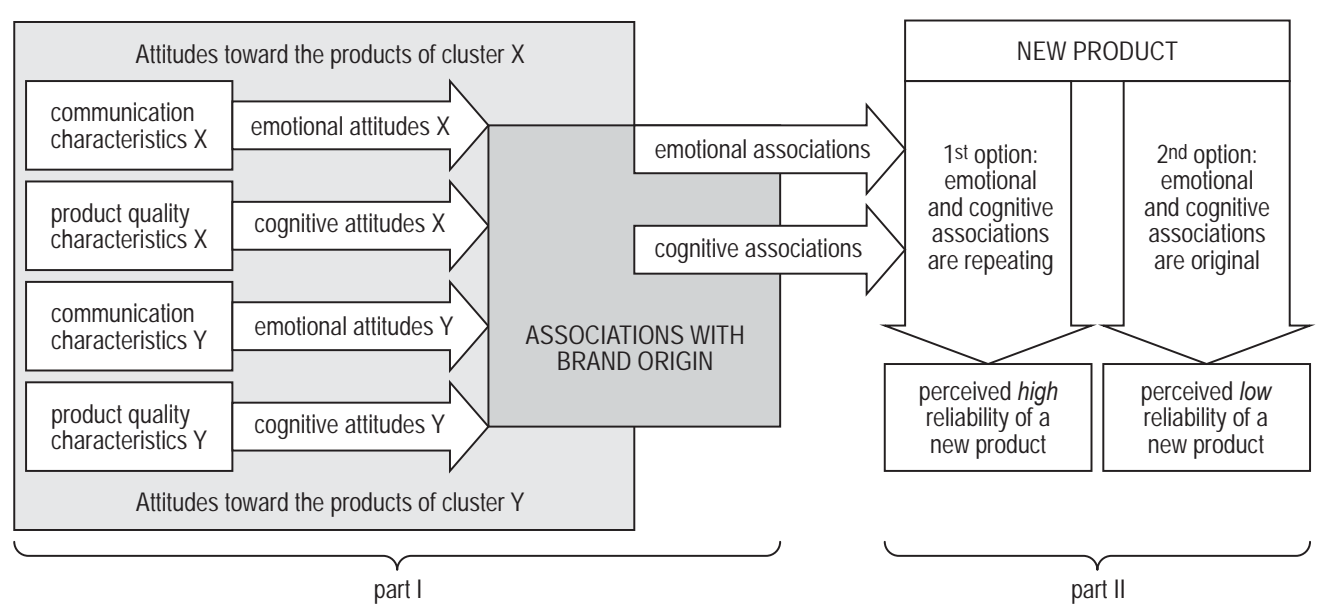

Fig. 1. A model of the effect of communication on consumers' perception towards brand origin and new product 
same origin if the product components are similar to prevailing in this region. Hence, we hypothesize that:

H 2: New products that contain the same emotional and cognitive components as products from dominant industries are perceived by consumers as more reliable for international consumers than the products without these components.

\section{The Baltic Sea Region as a brand origin}

Specifically, the empirical study of our research focuses on the case of the Baltic Sea region. This region is unique as it consists of economically different countries. More specifically, the business environment across the Baltic Sea Region exhibits strong heterogeneity (The State of the Region Report 2004), even among countries of similar prosperity (Tvaronavičienè et al. 2008) and this situation brings new capabilities for international business clustering. Consequently, the Baltic Sea Region has become increasingly active in cluster and competitiveness efforts in the national and global markets in recent years (The Baltic Sea Region as a Place ... 2007). Strong networking relations, established in the competitive environment, serve as the main driving forces of innovation in this region (Adekola et al. 2008). This expansion can be explained by guarantees associated with products, that are supported by positive cognitive and emotional components. The Baltic Sea region is a good case for analysis as Baltic Development Forum is exploring the possibility to brand this region as the "top of Europe" in terms of economic growth, educational levels, innovation, research and development (Kalnins 2007).

On the other hand, countries of the Baltic Sea Region are evaluated differently by the consumers concerning a brand origin. For example, Finnish brands are conveying an image of Nordic life that is progressive, responsible and technologically advanced (Ryan 2008). Danish brands are advertised as being of a superior quality due to the use of local dairy output produced under traditional practices (Regmi and Gehlhar 2005). At the same time, Lithuania, Latvia and Estonia are perceived as one region where a complex process of political, economic and social transformation emerged (Melnikas 2008). For example, Estonian products are perceived as good value for the money, whereas Polish brands are found to be technically superior (Kaynak and Eronen 2004). These examples show the perceptional differences between countries and raise the query whether this region can serve as a homogeneous brand. Following that, we analyse not only the associations with brand origin of the clusters but also the perceptional homogeneity of this region.

\section{Method}

In order to test the model we used a pretested, selfadministered online questionnaire. The respondents in this research were the emigrants from the Baltic Sea region representing the UK and Spain as international consumers. Since the research population could not be identified reliably due to the unknown real amount of emigrants, the use of probability sample was impossible. Consequently, the sample was chosen on the basis of convenience and accessibility. The UK and Spain were selected as these areas are geographically dispersed and were expected to have variations in customers' perception. It was decided to study the model for food and telecommunication service products. These categories of these products were chosen as most consumers buy them on a regular basis. These products are manufactured in strong clusters in the Baltic Sea region and represent high employment size and dominance in the regional economy (The Baltic Sea Region as a Place ... 2007), moreover, the specific characteristic of the telecommunications and food industry is its perceived role within society (Jurkštienè et al. 2008).

By aiming to test the hypothesis the questionnaire was developed. Cognitive and emotional components firstly were tested on regional basis, afterwards the same components were checked on product basis. 1-4 brand names were chosen from each country of the Baltic Sea region from food and communication industries. Altogether 17 brand names were tested by asking respondents to evaluate cognitive and emotional components of the brands on five-point scale (ranging from 1 - very poor fit to 5 - excellent fit). Additionally, to test the second hypothesis, we created a tentative brand name and asked respondents to identify the attributes that influence their positive evaluation of the product.

Questionnaire was designed to test respondents' attitudes toward cognitive and emotional components of the selected brands. Drawing on the literature on brand origin, we adopted Van Ittersum et al. (2003) methodology to test cognitive components of the Baltic Sea region as a brand origin. The image of a brand origin is expected to be a construct of two dimensions: a human factor and a natural environment factor. The human factor represents the expertise in the region of origin for making the product (enough quality, enough knowledge, etc.), while the natural environment refers to the physical condition that influences the qualities of the product (sufficiently clean environment, etc.). In our questionnaire we used all seven human and five environment factors originated with van Ittersum et al. (2003). 
As for measuring cognitive components, we borrowed Vergult's (2008) typology of brand personality to test the emotional components. According to Vergult (2008), 34 brand personality statements can be grouped into 5 underlying dimensions: emotional, simple, aggressive, conscientious, and innovative.

The last section of the questionnaire included respondents' demographic variables. As the analysis implied two scores from each variable (associations with the region and associations with the brands), the paired comparison test was used.

The Internet link to online questionnaire was personally sent to 150 respondents by using snowball approach; 112 responses were obtained through this channel. An overall response rate was nearly 75 percent, which determined an extremely good response. This can be explained due to the use of nonprobability sampling. A total of 68 Spain and 44 UK residents completed and returned usable questionnaires for data analysis. The majority of respondents were $26-35$ years old $(59.8 \%$, $n=67)$, women $(70.5 \%, n=79)$. More than one third of the respondents had college education, whilst one fourth of the respondents had high school degree. The descriptive data of these demographics are given in Table 1.

Table 1. Frequency distribution of demographics

\begin{tabular}{lcc}
\hline \multicolumn{1}{c}{ Variable } & $\begin{array}{c}\text { Frequency } \\
(n=112)\end{array}$ & Percentage \\
\hline Age & 32 & \\
18-25 & 67 & 59.5 \\
$26-35$ & 11 & 9.8 \\
$36-45$ & 2 & 1.8 \\
46+ & 33 & \\
\hline Gender & 79 & 70.5 \\
Male & & \\
Female & 44 & 39.3 \\
\hline Residential area & 68 & 60.7 \\
$\quad$ UK & & \\
Spain & 37 & 33.0 \\
\hline Educational level & 31 & 27.6 \\
High school & & \\
College & & \\
Graduate School & 32 & 10.7 \\
$\quad \begin{array}{l}\text { Not finished } \\
\text { graduate school }\end{array}$ & 12 & \\
\hline
\end{tabular}

\section{Analysis of the results}

Each emotional $(\mathrm{N}=34)$ and cognitive $(\mathrm{N}=12)$ dimension was measured and the scores were obtained for the region and each brand name (Table 2). Furthermore, and in order to facilitate the use of statistical tools, each individual's sequence was aggregated and the attribute correlation matrices were calculated and
Table 2. Descriptive analysis of construct

\begin{tabular}{|c|c|c|c|}
\hline \multirow[t]{2}{*}{$\begin{array}{l}\text { Variable group } \\
\text { (qty of variable } \\
\text { in each) }\end{array}$} & \multirow{2}{*}{ 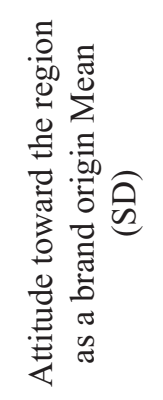 } & \multicolumn{2}{|c|}{$\begin{array}{l}\text { Identified components in } \\
\text { the communication on } \\
\text { the brands Mean (SD) }\end{array}$} \\
\hline & & Food & $\begin{array}{l}\text { telecom- } \\
\text { munication }\end{array}$ \\
\hline $\begin{array}{l}\text { Emotional: } \\
\text { innovative (10) }\end{array}$ & 2.4( & $1.2(1.00)$ & $4.1(3.59)$ \\
\hline simple (4) & 3.7( & $4.2(0.92)$ & $2.8(1.47)$ \\
\hline emotional (7) & $1.2(1$ & $1.1(1.04)$ & $1.9(2.37)$ \\
\hline aggressive (4) & $2.4(2-r) r)$ & $1.3(1.23)$ & $3.2(3.71)$ \\
\hline conscientious (9) & $3.8(2.10)$ & $4.1(2.10)$ & $3.0(1.09)$ \\
\hline $\begin{array}{l}\text { Cognitive: } \\
\text { human (7) } \\
\text { natural }\end{array}$ & $4.3(1.54)$ & $4.5(1.98)$ & $4.1(1.15)$ \\
\hline environment (5) & $2.1(2.52)$ & $1.4(2.20)$ & $2.5(2.89)$ \\
\hline
\end{tabular}

subjected to principal component analysis. The components extracted were using the varimax procedure, orthogonally rotated. From this procedure, seven components accounting for approximately $79 \%$ of the total variation on attitudes toward the Baltic Sea region as a brand name were identified: as emotional components: mature and credible (group "conscientious"), familiar (group "simple"), modern (group of "innovative"); as cognitive components such human factors emerged as enough quality, enough knowledge, and enough tradition. The same method was used to build the model of the components in the communication with the consumers on the brands from food and telecommunication industries.

In the food industry such components as credible and familiar, enough quality and tradition account nearly to $62 \%$. In the telecommunication industry the following components were identified: mature, familiar, modern and innovative, enough quality, knowledge, and tradition $(71 \%)$.

In order to test the first hypothesis, Person's correlation was used. We tested the relationship between consumer attitude toward the Baltic Sea region and components in the communication on the brands. Respondents gave high evaluations for telecommunication brands on innovativeness, but the correlation between region and brands innovativeness was low $(r=0.12)$, whereas correlations between other attitudes and components in the communication were very strong: for mature $r=$ 0.73 (food) and $r=0.80$ (telecommunication), in that order for credible $-0.84 / 0.87$, for familiar $-0.62 / 71$, 
for modern $-0.66 / 0.89$, for enough quality $-0.84 / 81$, for enough knowledge $-0.61 / 0.75$, and for enough tradition $-0.86 / 67$. Consequently, we can maintain that the brand names from food and telecommunication industries create emotional associations as credible, familiar and modern and cognitive associations as enough quality, enough knowledge, and enough tradition. Table 3 shows the relationships between emotional and cognitive components of region and brands, which shows high interdependence too.

To test hypothesis two, attractiveness of a tentative brand name was tested. Varimax procedure was applied repeatedly aiming to develop a new model of influencing factors. In the case of new product, all the same components have lumped together, except familiar. Mature, credible, modern, enough quality, knowledge and tradition compose the first model (71\%). Strong correlation between attributes of known and new products was identified $(0.84-0.91)$. Thus, the results provide evidence for confirming the second hypothesis.

\section{Conclusions}

Consumer perceptions of brand origin have been investigated widely over the years. Marketing researchers continue to show great interest in this research paradigm. This is because researchers realize the importance of the consumer perceptions of brand origin as one of the main influencing factors in consumer decision making process. However, most of these studies are undertaken on the basis of one country as a brand origin. Hence, neither the empirical findings nor the conceptual frameworks of these studies can be directly extrapolated to the domain of international region. This study is one of the first attempts at filling this gap in international region as a brand origin.

The results of the theoretical analysis of this study provide a foundation for making suggestions about theoretical relationships between components of the brand origin. According to proposed theoretical model, communication with the consumers spreading from the strong business clusters in the region creates emotional

Table 3. Pearson correlation coefficient between respondents' attitude toward the Baltic Sea region as a brand and perception of the communication on the brands on emotional and cognitive level

\begin{tabular}{|c|c|c|c|c|c|c|}
\hline & \multicolumn{2}{|c|}{$\begin{array}{l}\text { Attitude toward the } \\
\text { region as a brand origin }\end{array}$} & \multicolumn{2}{|c|}{$\begin{array}{l}\text { Identified components in } \\
\text { the communication on the } \\
\text { brands in food industry }\end{array}$} & \multicolumn{2}{|c|}{$\begin{array}{l}\text { Identified components in the } \\
\text { communication on the brands } \\
\text { in telecommunication }\end{array}$} \\
\hline & emotional & cognitive & emotional & cognitive & emotional & cognitive \\
\hline \multicolumn{7}{|l|}{$\begin{array}{l}\text { Attitude toward the region } \\
\text { as a brand origin: }\end{array}$} \\
\hline Emotional (r) & 1.000 & - & 0.706 & - & 0.823 & - \\
\hline Sig.(2-tail) & - & & 0.00 & & 0.00 & \\
\hline $\mathrm{N}$ & 112 & & 110 & & 110 & \\
\hline Cognitive (r) & - & 1.000 & - & 0.687 & - & 0.743 \\
\hline Sig.(2-tail) & & & & 0.01 & & 0.01 \\
\hline $\mathrm{N}$ & & & & 109 & & 109 \\
\hline $\begin{array}{l}\text { Identified components in } \\
\text { the communication on the } \\
\text { brands in food industry: }\end{array}$ & - & - & - & - & - & - \\
\hline Emotional (r) & 0.706 & - & 1.000 & - & - & - \\
\hline Sig.(2-tail) & 0.00 & & & & & \\
\hline $\mathrm{N}$ & 110 & & & & & \\
\hline Cognitive (r) & - & 0.687 & - & 1.000 & - & - \\
\hline Sig.(2-tail) & & 0.01 & & & & \\
\hline $\mathrm{N}$ & & 109 & & & & \\
\hline $\begin{array}{l}\text { Identified components } \\
\text { in the communication } \\
\text { on the brands in } \\
\text { telecommunication: }\end{array}$ & - & - & - & - & - & - \\
\hline Emotional (r) & 0.823 & - & - & - & 1.000 & - \\
\hline Sig.(2-tail) & 0.00 & & & & & \\
\hline $\mathrm{N}$ & 110 & & & & & \\
\hline Cognitive (r) & - & 0.743 & - & - & - & 1.000 \\
\hline Sig.(2-tail) & & 0.01 & & & & \\
\hline $\mathbf{N}$ & & 109 & & & & \\
\hline
\end{tabular}


attitudes towards a brand origin; in addition, the quality of the products of the same clusters creates cognitive attitudes towards a brand origin. Performed empirical research allowed the analysis of both emotional and cognitive components of the brand origin. Hence, the direct effects of the attributes of local brands on the brand origin were tested. Direct effect of identified attributes in communication on the attitudes toward brand origin was observed, as hypothesized. In the case of the Baltic Sea region the influencing model of seven components was identified for food and telecommunication industries. Mature, credible, familiar, modern, enough quality, knowledge, and tradition account for nearly $62 \%$ of the associations with the region. All these components correlate significantly $(0.64-0.87)$ with identified components in communication on the brands form the Baltic Sea region. Consequently, the first hypothesis was confirmed: the products from the industries of high employment intensity and dominance in the regional economy create the main emotional and cognitive associations with brand origin.

Another important finding of this research is empirical testing of the relationship between attitude toward a brand origin and new product from this origin. According to the study, consumers prefer and expect the same attributes of new product as the attributes of already known products. Hence, the second hypothesis is confirmed: new products that contain the same emotional and cognitive components as products from dominant industries are perceived by consumers as more reliable for international consumers than the products without these components.

There are some limitations in this study and thus future research should continue to test and to refine relationships investigated in the present study. Only products from food and telecommunication industries and only the Baltic Sea region as the origin were considered for evaluation in this study. Additionally, emigrants from the Baltic Sea region were chosen as respondents and too big familiarity with the products was able to arise. Future studies must explore how the underlying model works for a wider range of products, other international regions, and populations. The findings' failure to replicate is evidence of a limit to the generalizability of the results. Nevertheless, the results of this study confirm and extend conclusions of the recent researches conducted in different fields of brand origin. The results reveal the major influences on international region as a brand origin and enable to assess possibilities to increase the attractiveness of the Baltic Sea region. The study suggests that one of the main factors that determine the attractiveness of brand origin is long-term communication with the international consumers kept by companies and their brands.

\section{References}

Adekola, A.; Korsakienè, R.; Tvaronavičienė, M. 2008. Approach to innovative activities by Lithuanian companies in the current conditions of development, Technological and Economic Development of Economy 14(4): 595-611.

Ahmed, S. A.; d'Astous, A. 2007. Moderating effect of nationality on country-of-origin perceptions: English-speaking Thailand versus French-speaking Canada, Journal of Business Research 60(3): 240-248.

Ahmed, S.A.; d'Astous, A. 2008. Antecedents, moderators and dimensions of country-of-origin evaluations, International Marketing Review 25(1): 75-106.

Ahmed, S. A.; d'Astous, A.; Eljabri, J. 2002. The impact of technological complexity on customers' perceptions of product made in highly and newly industialized countries, International Marketing Review 19(4): 387-407.

Alexander, B.; Shapero, E.; Arnold, P. A.; Arnold, K. 2001. Investigating Geography. Arnold Publishing.

Cayla, J.; Eckhardt, G. M. 2007. Asian brands without borders: regional opportunities and challenges, International Marketing Review 24(4): 444-456.

Gürhan-Canli, Z.; Maheswaran, D. 2000. Cultural variations in country-of-origin effects, Journal of Marketing Research 37(3): 309-317.

Han, S.; Yoon, S.; Vargas, P. T. 2005. Think it's good, but feel it's bad: country-of-origin effect on cognition, affect, and behavior, Advances in Consumer Research 32(1): 263-264.

Jurkštienè, A.; Darškuvienè, V.; Dūda, A. 2008. Management control systems and stakeholders' interests in Lithuanian multinational companies: cases from the telecommunications industry, Journal of Business Economics and Management 9(2): 97-106.

Kalnins, O. 2007. A Baltic Sea Strategy - acting regionally, thinking globally. Baltic Rim Economies [online] [accessed 12 November 2008]. Available from Internet: <www.tse.fi/ pei/bre>.

Karunaratna, A. R.; Quester, P. G. 2007. Influence of cognition on product component country-of-origin evaluation in Asia Pacific, Journal of Marketing and Logistics 19(4): 349-362.

Kaufmann, H. R.; Durst, S. 2008. Developing inter-regional brands, EuroMed Journal of Business 3(1): 38-62.

Kaynak, E.; Eronen, J. 2004. Outsourcing by Finnish organizational buyers from Eastern and Central European suppliers: country-of-origin impact, Journal of Euromarketing 13(2/3): 9-28.

Melnikas, M. 2008. Integral spaces in the European Union: possible trends of the social, economic and technological integration in the Baltic Region, Journal of Business Economics and Management 9(1): 65-77.

Moon, B. J.; Jain, S. C. 2002. Consumer processing of foreign advertisements: roles of country-of-origin perceptions, consumer ethnocentrism, and country attitude, International Business Review 11: 117-138.

Mrugank, T. V. 1996.Brand origin: conceptualization and review, Journal of Consumer Marketing 13(3): 2-42.

Regmi, A.; Gehlhar, M. 2005. Processed Food Trade Pressured by Evolving Global Supply Chains, AmberWaves 3(1): 13-19. 
Roth, M. S.; Romeo, J. B. 1992. Matching product category and country image perceptions: A framework for managing country-of-origin effects, Journal of International Business Studies 23(3): 477-497.

Ryan, J. 2008. The Finnish country-of-origin effect: The quest to create a distinctive identity in a crowded and competitive international marketplace, Journal of Brand Management 16(1/2): 13-20.

The Baltic Sea Region as a place to do business. Baltic development forum. 2007 [online] [accessed 12 November 2008]. Available from Internet: < www.bdforum.org $>$.

The State of the Region Report 2004. An Assessment of Competitiveness in the Baltic Sea Region [online] [accessed 12 November 2008]. Available from Internet:< ww.ivorytower.se/documents/SoRRegion.pdf>.
Tvaronavičienè, M.; Ginevičius, R.; Grybaitè, V. 2008. Comparison of Baltic countries' development: practical aspects of complex approach, Verslas: teorija ir praktika [Business: theory and practice] 9(1): 51-64.

Van Ittersum, K.; Candel, M. J. J. M.; Meulenberg, M. T. G. 2003. The influence of the image of a product's region of origin on product evaluation, Journal of Business Research 56: 215-226.

Vergult, Ch. 2008. .EU branding study - What is the .EU tld standing for? Report - 2008 [online] [accessed 12 November 2008]. Available from Internet:<https://www.centr.org/ main/4607-CTR/version/1/part/12/data/Admin 14\%20-\%20 Linden-\%20.eu $\% 20$ branding $\% 20$ study.pdf?branch=main\& language $=$ default $>$. 